\title{
PLANT EFFICIENCY \\ An Analysis of the Losses of a Hydroelectric System
}

BY J. D. ROSS

The following paper is an analysis of the losses and efficiencies of the Seattle Municipal Light and Power plant for the year 1911.

Great care has been taken in these measurements and the results have been checked in as many ways as possible and instruments have been frequently calibrated. These figures are therefore believed to be a close approximation to the true values.

\section{General Description of Plant}

The Seattle plant is a hydroelectric system delivering water to two $1,500 \mathrm{kw}$. Pelton units and two $5,000 \mathrm{kw}$. turbine units under $600-\mathrm{ft}(183 \mathrm{~m}$.) head through two pipes approximately $3 \frac{1}{2}$ miles $\left(5.6 \mathrm{~km}\right.$.) long, one of which is $67 \frac{3}{4}(172 \mathrm{~cm}$.) and the other $49(124 \mathrm{~cm}$.) inside diameter. The current is transmitted at 60,000 volts through two lines to Seattle, a distance of 38.7 miles $(62.2 \mathrm{~km}$.), and is there distributed at 15,000 and 2,400 volts for use by approximately 20,000 customers and for the city street lighting.

Pipe Lines and Penstocks. The $67 \frac{3}{4}$-inch $(172 \mathrm{~cm}$.) pipe consists of $15,865 \mathrm{ft}$. $(4,835.6 \mathrm{~m}$.) of wood stave pipe dividing at a point $951 \mathrm{ft}$. $(289.8 \mathrm{~m}$.) from the power house into two 48-in. (122 cm.) riveted steel penstocks. The 49-in. $(124 \mathrm{~cm}$.) wood pipe joins onto a 48 -in. $(122 \mathrm{~cm}$.) riveted steel penstock at a point $1,008 \mathrm{ft}$. $(307.2 \mathrm{~m}$.) from the power house.

Careful tests were made on the $67 \frac{3}{4}$-in. wood stave pipe, using gages calibrated before and after. The pipe contains five steel elbows, where the curvature is greater than $20 \mathrm{deg}$. These elbows are made to a 15 -ft. $(4.57 \mathrm{~m}$.) radius and have angles 
respectively $92,55,60,65$, and 45 degrees. The loss in head of each elbow was measured by a differential pressure gage. The results of the test are given in detail in the following table:

Loss of Head in Feet in Various Parts of $67 \frac{3}{3}-$ in. (172 cm.) Wood Stave Pipe

\begin{tabular}{|c|c|c|c|c|c|c|c|c|c|c|c|}
\hline $\begin{array}{c}\text { Vel- } \\
\text { ocity } \\
\text { in } \mathrm{ft} . \\
\text { per } \\
\text { second }\end{array}$ & $\begin{array}{l}\text { Loss } \\
\text { in } \\
\text { entry } \\
\text { and } \\
\text { screens }\end{array}$ & $\begin{array}{c}\text { E1- } \\
\text { bow } \\
\text { No. } 1 \\
92^{\circ}\end{array}$ & $\begin{array}{c}\text { E1- } \\
\text { bow } \\
\text { No. } 2 \\
55^{\circ}\end{array}$ & $\begin{array}{c}\text { El- } \\
\text { bow } \\
\text { No. } 3 \\
60^{\circ}\end{array}$ & $\begin{array}{c}\text { E1- } \\
\text { bow } \\
\text { No. } 4 \\
65^{\circ}\end{array}$ & $\begin{array}{c}\text { E1- } \\
\text { bow } \\
\text { No. } 5 \\
45^{\circ}\end{array}$ & $\begin{array}{c}\text { Total } \\
\text { loss } \\
\text { in } \\
\text { pipe }\end{array}$ & \begin{tabular}{|} 
Fric- \\
tion \\
loss \\
after \\
deduct- \\
ing en- \\
try and \\
elbows
\end{tabular} & \begin{tabular}{|c|} 
Loss \\
in $67 \frac{3}{4}$ \\
stave \\
pipe \\
per \\
1,000 \\
feet
\end{tabular} & $\begin{array}{c}\text { Value } \\
\text { of C. in } \\
\text { Kut- } \\
\text { ters } \\
\text { for- } \\
\text { mula }\end{array}$ & $\begin{array}{l}\text { Value } \\
\text { of N. in } \\
\text { Kut- } \\
\text { ters } \\
\text { for- } \\
\text { mula }\end{array}$ \\
\hline 2$\}$ & .06 & .03 & .03 & .03 & .03 & .01 & 4.1 & 3.91 & .246 & 134.06 & .01190 \\
\hline$B$ & .25 & .09 & .08 & .08 & .08 & .05 & 15.4 & 14.77 & .931 & 137.96 & .01175 \\
\hline 71 & .54 & .25 & .18 & .19 & .20 & .14 & 33.9 & 32.40 & 2.0425 & 139.71 & .01165 \\
\hline 10 & 1.14 & .46 & .34 & .36 & .37 & .27 & 61.9 & 58.96 & 3.775 & 137.01 & .011865 \\
\hline
\end{tabular}

Note: $1 \mathrm{ft} .=0.3048 \mathrm{in}$.

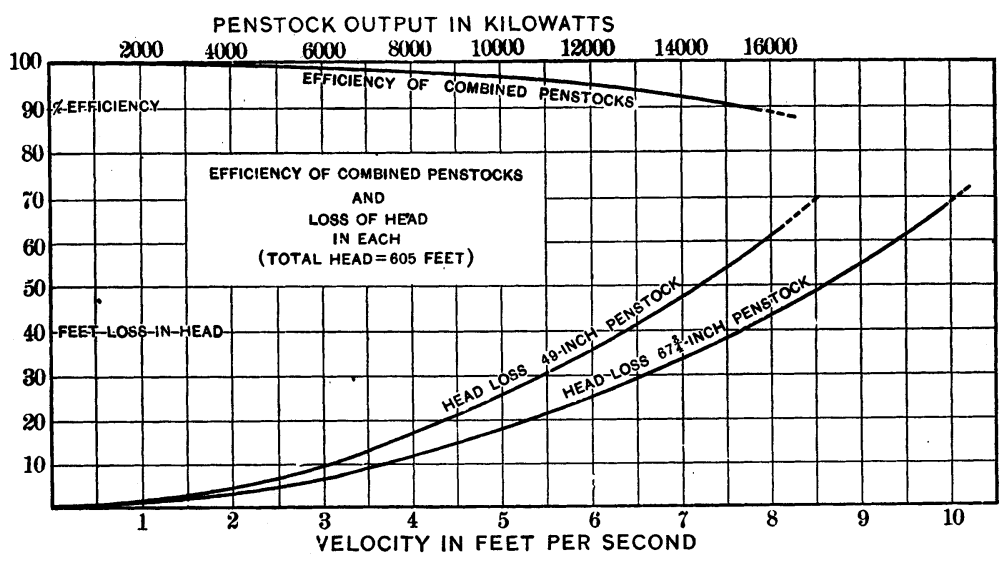

Fig. 1

This pipe has been in operation since November 20, 1908. The loss in entry as given in the above table seems large and rises with the velocity more rapidly than it should. This is apparently due to the resistance of the screens, which are of wood bars. These were being changed before the test was made as it was noiciced at times of heavy load that there was a difference of level on the two sides of the screens. The entry of the pipe is bell-mouthed. The total length of the wood pipe is $15,865 \mathrm{ft}$. $(4,835.6 \mathrm{~m}$.) The line was designed for a slope of four feet per thousand feet to give a velocity of ten feet $(3.05 \mathrm{~m}$.) per second. 
The loss in the penstocks was computed from records taken by Bristol recording gages at the generating station, which were frequently calibrated. The results so obtained were checked by computing the loss from the efficiency shown under test, and agreed very closely. The maximum output of the two penstocks was $12,400 \mathrm{kw}$., with a loss of 6 per cent, and the average output for the year was $6,009 \mathrm{kw}$., with an average loss of 2.3 per cent. This loss was increased by the fact that the plant was supplied for thirty-three days in November and December by the larger pipe alone.

Generating Station. There are four units in the power house, two of which consist of 8,000-h.p. Francis turbines directconnected to 60 -cycle, 2,300-volt, three-phase generators rated at $4,000 \mathrm{kw}$. at $35 \mathrm{deg}$. cent. rise, with a four hour overload capacity of $5,000 \mathrm{kw}$. at $40 \mathrm{deg}$. cent. rise. These units operate at $600 \mathrm{rev}$. per min. The other two units are driven by 2,400 h.p. Pelton impulse wheels direct-connected to 60-cycle, 2,300volt, three-phase generators rated at $1,200 \mathrm{kw}$. at $35 \mathrm{deg}$. cent. rise, with a four hour overload capacity of $1,500 \mathrm{kw}$. at $40 \mathrm{deg}$. cent. rise. These units operate at $400 \mathrm{rev}$. per min. The wheels are each equipped with two runners, each of which is supplied from a needle and a deflecting nozzle. The combined capacity of the present installation is therefore $13,000 \mathrm{kw}$. on a $40 \mathrm{deg}$. cent. rating. The two machines last mentioned, however, exceed their rating and have been operated continuously without excessive heating at $1,750 \mathrm{kw}$., making the combined capacity $13,500 \mathrm{kw}$. Three water wheel exciter units are installed, two of which have a capacity of $75 \mathrm{kw}$. each, and the third $150 \mathrm{kw}$.

As the efficiency of each unit varies with the load, and it is obviously impossible to have all generators that are in use ai any time carry their full load, the all-day efficiency of the generating station will depend on the number of units in use and the load which each carries, as well as on the power factor of the load and, in the case of this plant, where two types of wheels are used, it will also depend on the proportion of the load that the operator gives to each type of machine. In general, the greatest all-day efficiency can be had by keeping the machines as nearly as possible at the load of maximum efficiency, and by shutting down the machines without load as far as can conveniently be done.

While the combined maximum efficiency of generator and wheel was found in the case of the $5,000 \mathrm{kw}$. units to be 76.7 
per cent, and in the case of the $1,500-\mathrm{kw}$. units to be 69.9 per cent, the all-day efficiency of the plant for 1911 was found to be 56.7 per cent. This does not include current for excitation and station lighting. By including this as a loss, the all-day efficiency of the plant drops to $\mathbf{5 5 . 7}$ per 100 cent.

The reason for the difference in the same type of unit is found in the fact that the operators favor No. 1 and No. 4 machines, from habit rather than intention. The impulse wheels, being small, are operated under full load for a great part of the day and their all-day efficiency is greater than that of the turbines, notwithstanding the higher efficiency of the turbine sets at full

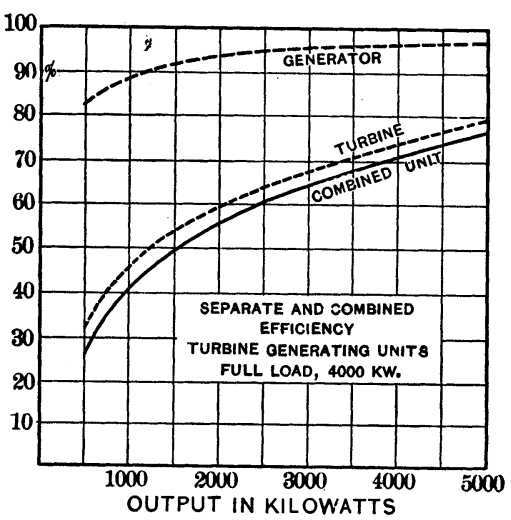

FIG. 2

load. It will be readily seen from these facts that the efficiency of a plant depends very largely on the way it is handled by the operator and during low water periods it is possible to prepare a schedule showing which machines should be used for each load

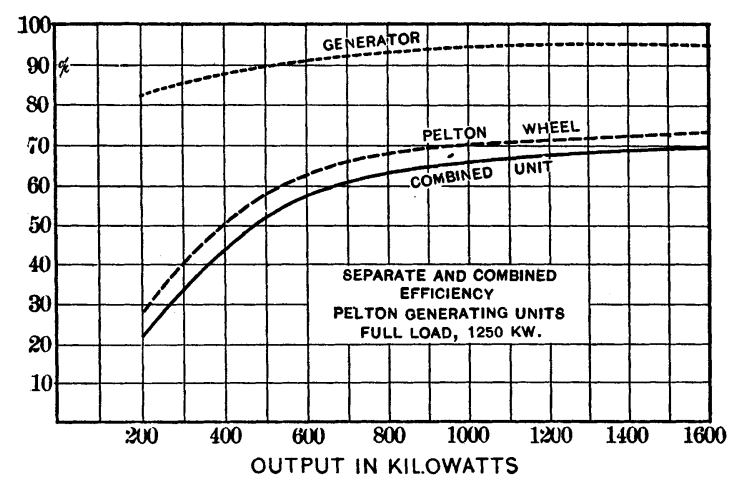

FIG. 3

which the plant carries. This schedule will be modified by the conditions of the plant, changes in load, and regulation.

Losses in the water wheels and generators were computed from the half-hour wattmeter readings on the generators as recorded in the station report. The input for each output 
throughout the year was computed from efficiencies shown in tests made in 1909 and checked at the end of 1911. The results show all-day efficiencies for the year as follows:

\begin{tabular}{|c|c|c|c|}
\hline \multicolumn{4}{|c|}{ EFFICIENCY } \\
\hline & Wheel & Generator & Combined \\
\hline Impulse Unit No. $1 .$. & 70.8 & 93.0 & 65.8 \\
\hline Impulse Unit No. 2. & 66.3 & 92.2 & 61.1 \\
\hline Turbine Unit No. 3.. & 57.1 & 93.0 & 53.1 \\
\hline Turbine Unit No. 4. & 63.6 & 94.1 & 59.8 \\
\hline Four units combined. & 60.7 & 93.5 & 56.7 \\
\hline
\end{tabular}

The higher efficiency of the impulse units is due to the fact that they were nearly always loaded above $900 \mathrm{kw}$. and the regulating was done with the relief valves and governors on the turbines, so that there was little loss from the deflecting nozzles.

The power used in excitation was computed from the halfhour readings on the exciter outputs, and amounted to 399,120 $\mathrm{kw}-\mathrm{hr}$. or 1.3 per cent. of the output of the generators. The water input to the exciter units, computed similarly to that of the large units, was $665,200 \mathrm{kw}-\mathrm{hr}$. Station lighting, including light for the employees' cottages, amounted to $175,000 \mathrm{kw}-\mathrm{hr}$. for the year.

Step-Up Transformers. The station is equipped with nine transformers. Each bank of three has a normal capacity of $4,500 \mathrm{kw}$. at $35 \mathrm{deg}$. cent. temperature rise. These transformers step the voltage from 2,300 to 60,000 volts three-phase star connected. The neutral of the star connection is grounded. The manufacturers were requested to sacrifice efficiency for high insulation, if necessary, but the efficiency is found to be as high as is customary when using lower insulation. These transformers

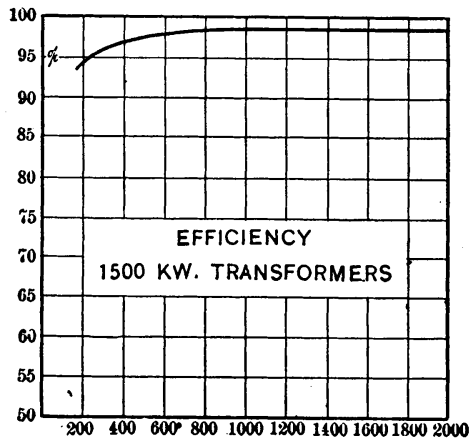

Fig. 4 were all in circuit continuously to keep them in good condition, and their core losses were practically constant, amounting to $926,000 \mathrm{kw}-\mathrm{hr}$., or an average of $11.7 \mathrm{kw}$. per transformer. The copper loss was computed from the readings on the reports, and 
amounted to $200,00 \mathrm{kw}-\mathrm{hr}$. or an average of $2.54 \mathrm{kw}$. per transformer.

\begin{tabular}{|c|c|c|}
\hline Cor & $\begin{array}{l}\text { Kw-hr. } \\
926,000\end{array}$ & $\begin{array}{c}\text { Average kw. } \\
106\end{array}$ \\
\hline loss. & 200,000 & 23 \\
\hline Total loss.. & $1,126,000$ & 129 \\
\hline
\end{tabular}

High-Tension Lines. There are two high-tension lines 38.7 miles $(62.2 \mathrm{~km}$.) in length strung on two different makes of insulators of practically the same size and type. One of the lines is of No. 2 solid medium hand-drawn copper, the wires being

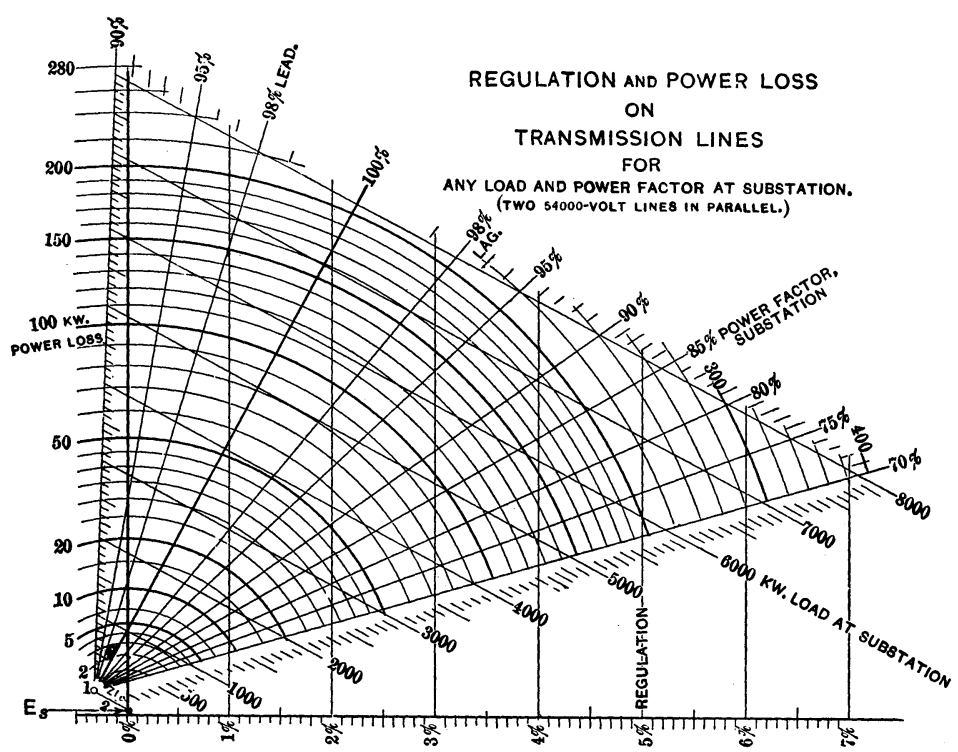

FIG. 5

placed in a six-foot $(1.83 \mathrm{~m}$.) triangle. The other is built of No. 0000 seven-strand hard-drawn copper, the wires being placed in a seven-foot $(2.13 \mathrm{~m}$.) triangle.

The line loss was computed from the constants of the lines, taking the load data shown by the report sheets. The line resistances were measured by direct current, using the fall of potential method, and agreed very closely with the computed value. The inductance and capacity were calculated from the values given in the Standard Handbook, third edition. To simplify calculation for the all-day efficiency, a Perrine-Baum regulation diagram was drawn for both lines in parallel. To this 
were added circles, taking as a center the end of the substation voltage vector, and as a radius the square of the voltage drop in the line, multiplied by the conductance of the line. The radii of these circles represent power loss. The power lost during 1911 on the two lines, figured from this diagram, using the halfhour readings at the substation for load data, amounted to $378,000 \mathrm{kw}-\mathrm{hr}$. or an average of $43 \mathrm{kw}$. for the year.

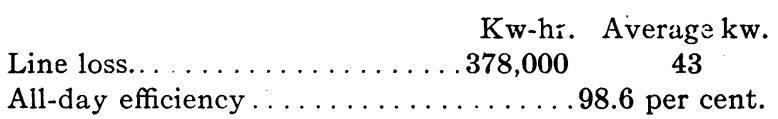

Step-Down Transformers. The step-down transformers are placed on the first floor of the substation. There are at present eight of these, each of $1,500 \mathrm{kw}$. capacity at $35 \mathrm{deg}$. cent. temperature rise. All are made with a ratio of 54,000 volts, threephase to 15,000 and 2,500 Scott connected two-phase, making four banks of transformers. The low-tension coils are connected in series for 15,000 and in multiple for 2,500 volts, two banks being used on each voltage.

The step-down transformer loss, computed in the same way as that of the step-up transformers, was as follows:

$\mathrm{Kw}$-hr. Average kw.

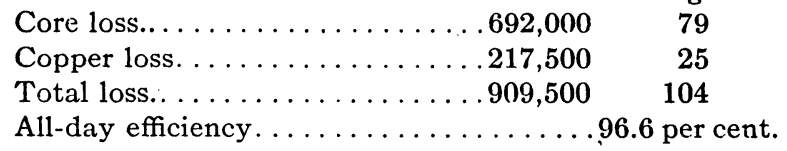

The sum of the losses in line and transformers was checked against the difference in the watt-hour meter readings on the low-tension side of the transformers at each end of the line, and was about five per cent lower. This may not have been due to error but may be largely due to corona loss or other line leakage. No measurements have as yet been made to determine this point.

Main Substation. The main substation contains the stepdown transformers, a distributing switchboard of the remote control type, and the necessary switching and control apparatus for the distributing feeders. The switchboard carries a complete set of curve-tracing meters for the high-tension lines, indicating ammeters and wattmeters and watt-hour meters for the transformers, and indicating ammeters, recording voltmeters and watt-hour meters for the feeders. - Loss in meters and their instrument transformers was computed from tests 
made on each type of meter and transformer. Current used for station light, heat and display lighting was metered.

$\mathrm{Kw}$-hr. Average kw.

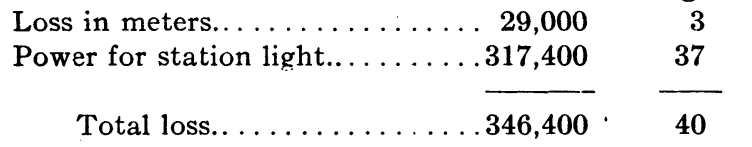

All-day efficiency............98.7 per cent.

Motor-Generator Set. A motor-generator set consisting of a 750-h.p., two-phase synchronous motor direct-connected to two $250-\mathrm{kw}$. 250-volt direct-current compound-wound generators is used on a three-wire 500 and 250 -volt system for operating elevators and other motors. The maximum load on this machine at the present time on the direct-current side is $300 \mathrm{kw}$. and the average load for 1911 was $30.2 \mathrm{kw}$. The surplus kilovolt-ampere capacity of the motor is utilized in regulating the voltage of the main system by varying the power factor by means of a Tirrill regulator controlling the field of the motor. There are at present 71 services connected on this system with a connected load of 772 $\frac{1}{2}$ h.p. The main feeder is 750,000-cir. mil cable with a 400,000-cir. mil neutral, and the branches usually No. 4/0 with No. $2 / 0$ neutral. In all, 27 miles $(43.4 \mathrm{~km}$.) of wire are used on this system.

The total loss in the direct-current feeders and the motorgenerator was obtained from the difference in the motor watthour meters and the customers' meters. From recording voltmeter charts taken at various distributing points and at the substation and from computations, using the load data and line resistance, the line loss is placed at $\mathbf{5}$ per cent. The details of losses and efficiencies follow:

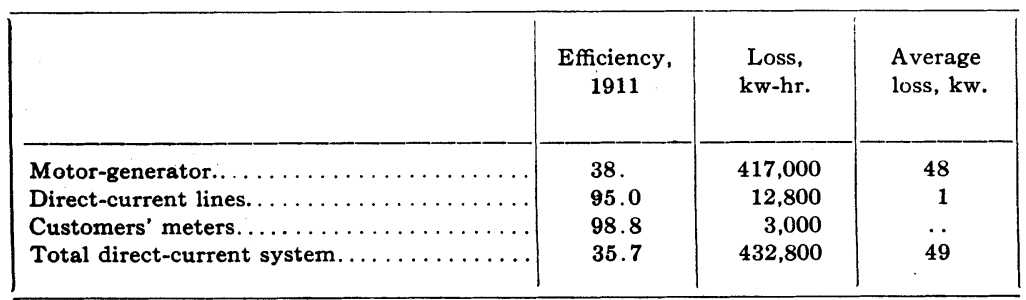

$15,000-$ Volt System. Current is distributed at 15,000 volts from the main substation to two smaller substations and to 
about twelve mills and factories which use large amounts of power. This system is two-phase, with the center point of each

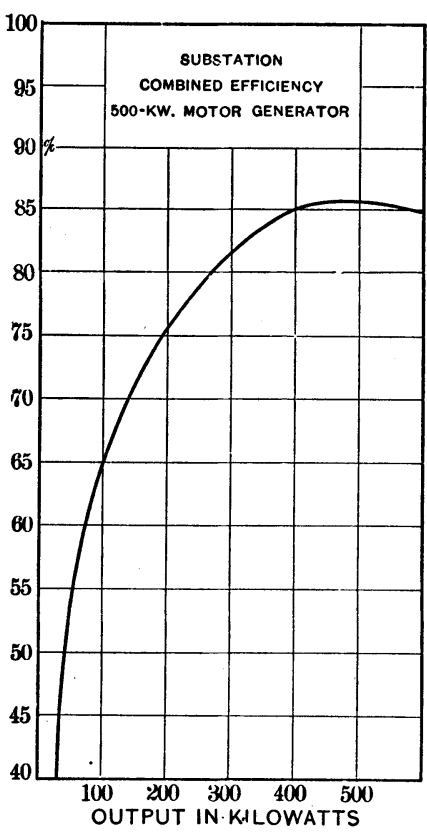

FIG. 6 phase grounded. For mechanical reasons, No. 2 is the smallest wire used on the 15,000 -volt lines. There are about 105 miles (169 $\mathrm{km}$.) No. 2, nine miles $(14.5 \mathrm{~km}$.) of No. 1, and two and one-half miles $(4.02 \mathrm{~km}$.) of No. 0 wire. There are 30 transformers connected, ranging in size from $750 \mathrm{kw}$. to $50 \mathrm{kw}$., with a combined capacity of $6,250 \mathrm{kw}$.

Loss in the 1,500 -volt system was found by taking the difference in the meter readings at substation and at the various receivers, and checked closely by calculation from the line constanis and load data. The transformer losses on this system were computed from the load data on the station reports and the tests taken on each size and type of transformer under actual operating conditions.

Copper loss is small compared to core loss because the transformers were lightly loaded; an installation of $6,250 \mathrm{kw}$. carried an average load of $1,323 \mathrm{kw}$. The detail losses were:

\begin{tabular}{|c|c|c|c|}
\hline & $\begin{array}{c}\text { Efficiency, } \\
1911\end{array}$ & $\begin{array}{l}\text { Loss, } \\
\text { kw-hr. }\end{array}$ & $\begin{array}{l}\text { Average } \\
\text { loss, kw. }\end{array}$ \\
\hline 15,000 -volt lines $\ldots \ldots \ldots \ldots \ldots \ldots$ & 99.2 & 93,500 & 11 \\
\hline 15,000 -volt transformers. $\ldots \ldots$ & 93.2 & 775,100 & 88 \\
\hline Core loss. . . . . . . . . . . & & 694,000 & 79 \\
\hline Copper loss................... & & 81,100 & 9 \\
\hline 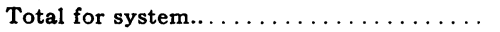 & 92.5 & 868,600 & 99 \\
\hline
\end{tabular}

2,400-Volt Distributing System. Power is distributed from the substations by means of seventeen 2,400 -volt primary feeders. Of these, twelve are fed from the main substation at Seventh Avenue and Yesler Way, three from Fremont substation and two from West Seattle substation. The more heavily loaded 
circuits were designed for 200 amperes and the lighter ones for 150 amperes. Number 4/0 wire was used at first, but the economic size for a 200 -ampere feeder has been computed at 350,000 cir. mils, which size is now used on the heavier feeders.

An area of 28 square miles $(72.5 \mathrm{sq} . \mathrm{km}$.) is served by this system extending seven miles $(11.2 \mathrm{~km}$.) south and six miles $(9.6 \mathrm{~km}$.) north of Yesler Way. A distributing point is established at the approximate center of distribution for each feeder, and the automatic regulators in this station are set to give the desired voltage at this point.

Connected to the 2,400-volt feeders are 1,082 distributing transformers, ranging in size from $2 \frac{1}{2} \mathrm{kw}$. to $50 \mathrm{kw}$., and with an aggregate full-load capacity of $9,268 \frac{1}{2} \mathrm{kw}$. They are connected to give a 240-120-volt three-wire low-tension winding, with the neutral grounded. To aid regulation, a number of transformers of the same size and type are usually connected together on the low tension side where conditions will permit. The secondary wire is generally No. 4 for the outside wires and No. 6 for the netural, with No. 8 for the services. The maximum voltage drop from transformer to customer is kept within 2 volt whenever possible, since there is no way of regulating for voltage between these points. The pressure at the service is kept as near 120 volts as possible. Although standard 2,200-110-volt transformers are used, the pressure has been raised to 2,400 volts, and it is planned to raise it still further to 2,500 volts. This gives about 25 per cent higher core loss, but lowers the copper loss in both transformers and feeders about 29 per cent, and in addition gives nearly 14 per cent better regulation. The 2,400-volt system used 545.4 miles $(877.7 \mathrm{~km}$.) of high-tension wire, ranging in size from No. 6 to 350,000 cir. mils, and $1,137.7$ miles $(1,830.9 \mathrm{~km}$.) of low-tension wire, varying from No. 6 to No. $4 / 0$.

Losses in the feeder regulators were computed trom tests made on each type used, in conjunction with load data from the station reports. Losses in distributing transformers were computed in the same way, using also recording ammeter charts taken at distributing points. Losses in the high-tension line were computed from the load data and line resistances of each feeder, and checked by recording voltmeter charts taken at the station and at each distributing point. Loss in low-tension line was estimated from line resistances and load data, and checked by recording voltmeter at the customers' services. Loss in the customers' meters was computed from tests on each type of meter in use. 
A check on the various distributing losses is furnished by the difference in the power metered to the customer and that delivered to the distributing system. This amount proved to be slightly greater than the sum of the losses as computed, and the difference was added to the loss in low-tension system, since that loss was most difficult to determine with accuracy. There is also probably a small amount of stolen current included in the low-tension loss. The details of losses on the 2,400-volt commercial system follow:

\begin{tabular}{|c|c|c|c|}
\hline & $\begin{array}{c}\text { Efficiency } \\
19\end{array}$ & $\begin{array}{l}\text { Loss, } \\
\text { kw-hr. }\end{array}$ & $\begin{array}{l}\text { Average } \\
\text { loss, kw. }\end{array}$ \\
\hline Feeder regulators. $\ldots \ldots \ldots \ldots \ldots \ldots \ldots$ & 98.6 & 178,500 & 20 \\
\hline Primary feeders. . . . . . . & 96.0 & 521,600 & 60 \\
\hline Distributing transformers... & 88.8 & $1,391,000$ & 159 \\
\hline Core loss........... & & 960,000 & 110 \\
\hline Copper loss. . . . . . . & & 431,000 & 49 \\
\hline Secondaries......... & 92.9 & 782,600 & 89 \\
\hline Customers' meters.. . . . . . . . . & 97.6 & 250,000 & 29 \\
\hline Total for system.............. & 76.2 & $3,123,700$ & 357 \\
\hline
\end{tabular}

Cluster Light System. The cluster light system comprises 1,631 poles, lighting 25 miles $(40.2 \mathrm{~km}$.) of street and carrying 6,851 lamps of a total of 335,700 watts. This system is supplied from $720 \mathrm{kw}$. in transformers using 23 miles $(37 \mathrm{~km}$.) of primary wire carrying 2,400 volts and 98.4 miles $(158.3 \mathrm{~km}$.) of secondary wire in a 240 - and 120-volt three-wire system. The voltage is changed from 120 volts to 8 volts in the base of the pole and 8-volt multiple lamps are used. Losses on this system were computed in a similar manner to those on the other distributing systems. They lack the check of integrating meters at the lamp, but were easier to compute on account of the constancy of the load. The transformer losses contain those from the pole-base transformers, which are 250 -watt, 8 -volt transformers.

\begin{tabular}{|c|c|c|c|}
\hline & $\begin{array}{c}\text { Efficiency, } \\
1911\end{array}$ & $\begin{array}{l}\text { Loss, } \\
\text { kw-hr. }\end{array}$ & $\begin{array}{l}\text { Average } \\
\text { loss, kw. }\end{array}$ \\
\hline Cluster light primaries. . & 97.0 & 42,500 & 5 \\
\hline Cluster light secondaries... & 93.0 & 86,500 & 10 \\
\hline Cluster light transformers. & 87.8 & 181,000 & 21 \\
\hline Core loss. $\ldots \ldots \ldots \ldots$ & $\ldots$ & 117,500 & 13 \\
\hline Copper loss. . . . . . . & & 63,500 & 7 \\
\hline Total for system.... & 79.1 & 310,000 & 35 \\
\hline
\end{tabular}


Series Street Lighting System. The series street light system comprises 683 miles $(1,099 \mathrm{~km}$.) of No. 6 wire divided into 29 circuits, lighting 601 miles $(967.2 \mathrm{~km}$.) of street. The circuits are connected two in series to 100-light air-cooled constant-

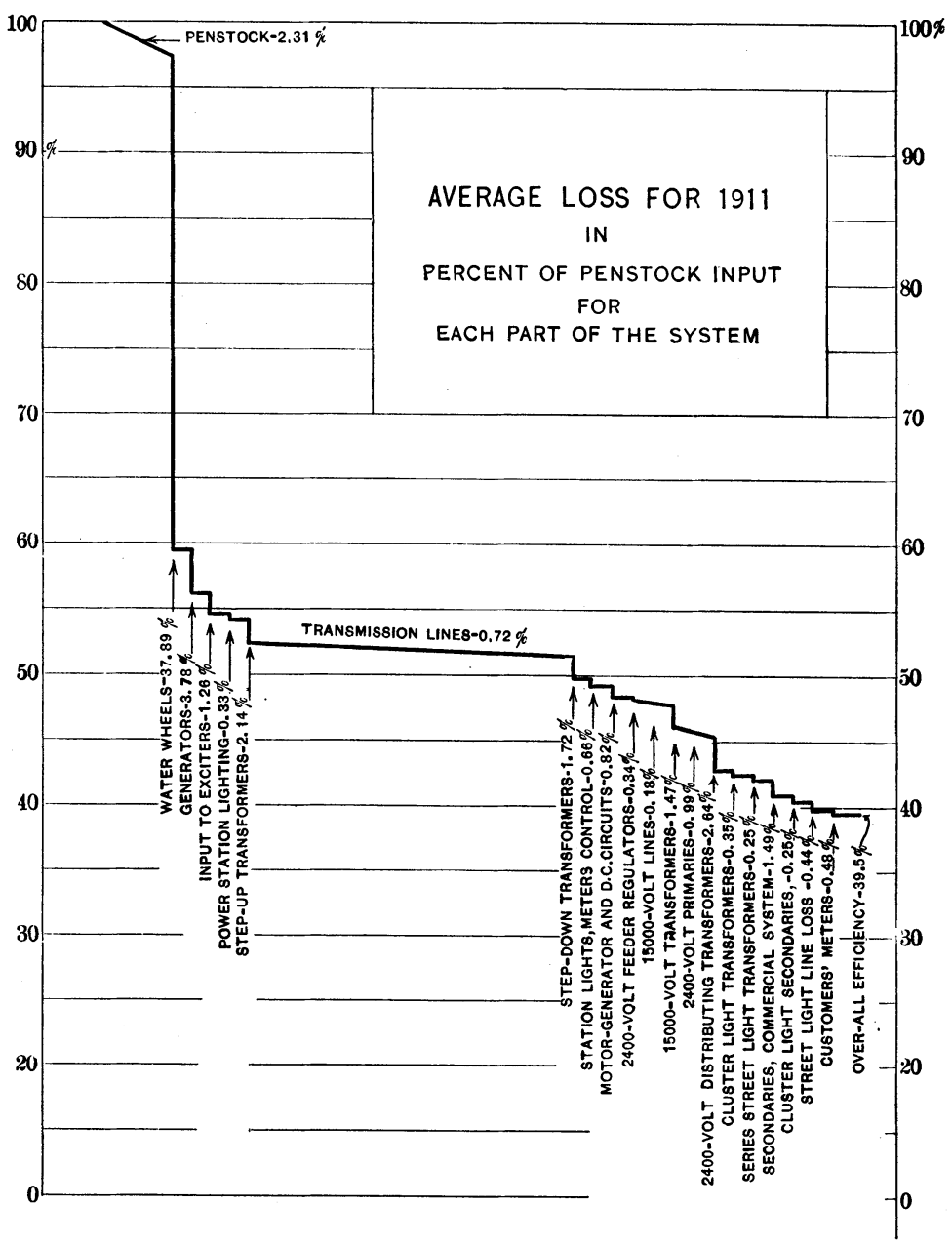

Fig. 7

current transformers. The voltage on the circuits varies with the number and kind of lamps from 2,500 volts to 5,000 volts. Altogether there are 692 6.6-ampere arc lamps, 5,315 40-candlepower tungsten lamps, and 199.300-candle-power tungsten lamps. 


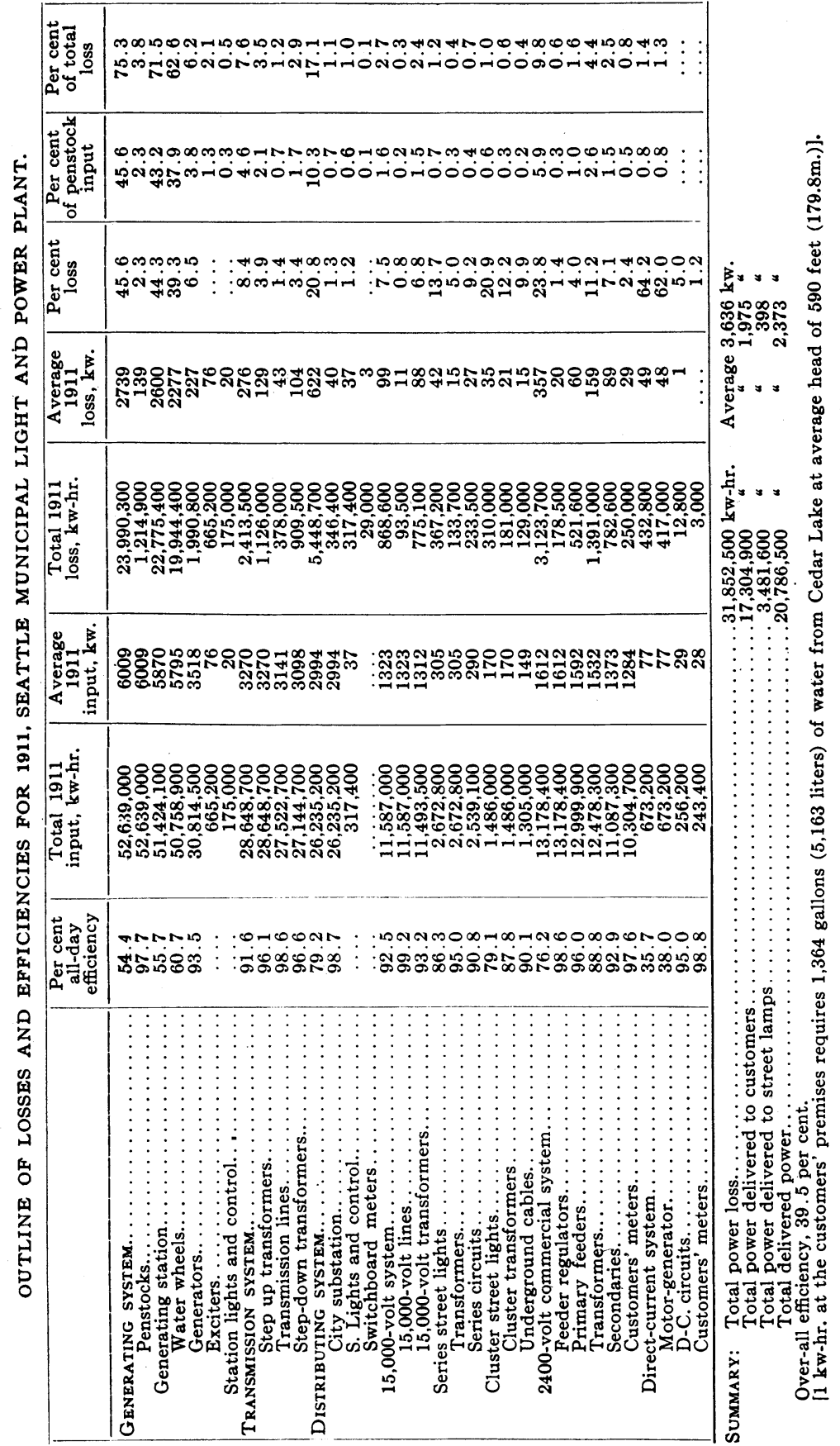


Losses were computed in a similar manner to those on the cluster light system, and were as follows:

\begin{tabular}{|c|c|c|c|}
\hline & $\begin{array}{c}\text { Efficiency, } \\
1911\end{array}$ & $\begin{array}{c}\text { Loss, } \\
\text { kw-hr. }\end{array}$ & $\begin{array}{c}\text { Average loss, } \\
\text { kw. }\end{array}$ \\
\hline Series lines...... & 90.8 & 233,500 & 27 \\
\hline Constant current transformers $\ldots \ldots \ldots \ldots$ & 95.0 & 133,700 & 15 \\
\hline Core loss. . . $\ldots \ldots \ldots \ldots \ldots \ldots$ & $\ldots$ & 63,900 & 7 \\
\hline 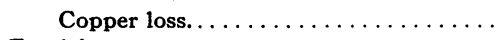 & $\ldots$ & 69,800 & 8 \\
\hline Total for system.................. & 86.3 & 367,200 & 42 \\
\hline
\end{tabular}

The table on the preceding page, shows the losses and efficiencies for each part of the system, and the accompanying diagram shows each loss expressed in per cent of penstock input.

The writer is indebted for very considerable assistance from Dr. C. E. Magnusson and Prof. Harris of the University of Washington in tests on pipe lines and generating units, and to Mr. Glen Smith of the City Light Department of Seattle for compilation of tests and data.

The generators and station transformers were also tested by the Electrical Testing Laboratories of New York. 